\title{
Habitat availability determines distribution patterns of spionid polychaetes (Annelida: Spionidae) around Tokyo Bay
}

\author{
Hirokazu Abe ${ }^{1,2,3^{*}} \mathbb{D}$, Toshimitsu Takeuchi ${ }^{2,4}$, Masanori Taru ${ }^{3}$, Waka Sato-Okoshi ${ }^{5}$ and Kenji Okoshi ${ }^{2,3}$
}

\begin{abstract}
An investigation of the distribution and habitat utilization of spionid polychaetes in Tokyo Bay revealed eight shellboring and 18 non-boring (interstitial, epifaunal, and infaunal) species, of these 11 species were recorded in the area for the first time. Most of the boring and interstitial species, which are associated with mollusc shells, were mainly distributed in exposed environments favoured by their host species outside Tokyo Bay. Only two boring species, Polydora websteri and Polydora haswelli preferred the enclosed waters of Tokyo Bay. Epifaunal and infaunal species were mainly distributed in the sandy and/or muddy sediment within Tokyo Bay. A widespread or localized distribution pattern within species was observed corresponding to the larval developmental mode. We concluded that habitat availability determines distribution patterns of spionid polychaetes around Tokyo Bay. Novel habitats for Boccardiella hamata, Boccardia proboscidea, Carazziella spongilla, and Polydora cornuta were recorded. Boccardia pseudonatrix, which was recorded for the first time from Japan with clear locality information, is considered to be a potential alien species.
\end{abstract}

Keywords: Polydorids, Habitat type, Host utilization, Distribution trend, Boring, Tokyo Bay

\section{Introduction}

The family Spionidae, one of the largest and most diverse taxa of polychaetous annelids, is a major component of marine and estuarine benthic communities all over the world. The spionids are widely distributed from deep-sea to freshwaters (e.g. Glasby and Timm 2008; Paterson et al. 2016). The group is well known to utilize various substrates such as bottom sediment, sand or mud deposits in crevices of stones, rocks, shells, and byssus and to associate with other invertebrates. Some spionids can bore into various hard calcareous substrates (Blake and Evans 1972). Shell boring ability is considered to be species specific (Sato-Okoshi 1999, 2000), although there are some exceptions (e.g. Radashevsky and Pankova 2013). In addition to the ability to exploit a wide range of habitats that are not utilized by other invertebrates (Blake 1996), the great plasticity in feeding methods (Dauer et al. 1981) and diverse reproduction

\footnotetext{
* Correspondence: habe@iwate-med.ac.jp; abehiro13@gmail.com

${ }^{1}$ Department of Biology, Center for Liberal Arts \& Sciences, Iwate Medical

University, 2-1-1 Nishitokuta, Yahaba-cho, Shiwa-gun, Iwate 028-3694, Japan

${ }^{2}$ Department of Environmental Science, Faculty of Science, Toho University,

2-2-1 Miyama, Funabashi, Chiba 274-8510, Japan

Full list of author information is available at the end of the article
}

and developmental modes (Blake and Arnofsky 1999) are presumed to play an important role in the evolutionary success of spionids.

Spionid polychaetes, especially in polydorids (the genera: Polydora, Dipolydora, Pseudopolydora, Boccardia, Polydorella, Tripolydora, Boccardiella, Carazziella, and Amphipolydora), are well known as invasive polychaetes worldwide and pose a potential risk of marine biological invasion (Çinar 2013). In most cases, the invasion pathway of spionids is considered to be through ship fouling or ballast water (Carlton 1985; Çinar 2013). Additionally, anthropogenic translocation of molluscs for aquaculture is a significant invasive pathway for spionids, which bore into, or associate with, commercially important molluscs (Simon and Sato-Okoshi 2015). The rapid globalization and increasing trends of the living shellfish trade worldwide in recent decades have accelerated marine biological invasions of the boring spionid polychaetes (Radashevsky and Olivares 2005; Sato-Okoshi et al. 2008). Biological invasions are one of the most important direct drivers of biodiversity loss and a major pressure on several types of ecosystems (Katsanevakis et al. 2014). Nevertheless, little attention has been paid to

(c) The Author(s). 2019 Open Access This article is distributed under the terms of the Creative Commons Attribution 4.0 International License (http://creativecommons.org/licenses/by/4.0/), which permits unrestricted use, distribution, and 
marine biological invasions, especially in unintentionally transported species including spionids (Sato-Okoshi et al. 2012). An understanding of basic ecology, including environmental preference and habitat utilization patterns of the spionids which pose a potential risk of marine biological invasion, is useful for the prediction of their expansion and of the potential ecological impacts when the species invade a new geographical region. In particular, such studies in areas which include big international trading ports and thus susceptible to biological invasions would provide valuable information in the context of the real invasion problems.

Tokyo Bay, which is surrounded by Boso Peninsula and Miura Peninsula (Fig. 1), is one of the biggest 'melting pots' of alien species in Asia as a consequence of the presence of Tokyo Port, one of the biggest international trading ports in Japan (Asakura 1992; Iwasaki 2006). Extensive loss of tidal flats by reclamation has occurred in the twentieth century (Furukawa and Okada 2006). Owing to a large population and intensive industrial activity surrounding the bay, eutrophication often leads to seasonal hypoxia of bottom waters. Wind-driven coastal upwelling of the hypoxic water sometimes causes mass mortality of marine organisms (Takeda et al. 1991).
Although Tokyo Bay connects to open ocean adjacent to the Sagami Gulf via the Uraga Channel, water exchange is limited by the narrow width $(7 \mathrm{~km})$ of the channel (Fig. 1; Sukigara and Saino 2005). Huge environmental differences between the inside (north of the boundary line from Cape Futtsu on Boso Peninsulato to Cape Kannonzaki on Miura Peninsula, an enclosed bay) and outside (Uraga Channel and open ocean) of Tokyo Bay allow an evaluation of the environmental preferences of spionid species.

In the present study, to reveal the distribution of the spionid fauna occurring around Tokyo Bay and the detection of potentially invasive alien species, a field survey across a wide variety of habitats was carried out. This was also intended to indicate environmental preferences and habitat utilization patterns of the spionids, as well as the relationships between habitat availability and distribution pattern especially focused on the polydorid spionids.

\section{Methods}

Sampling of spionid polychaetes was conducted at 24 sites around Tokyo Bay (Fig. 1; outside of the bay: A-I, inside of the bay: J-X) during the period from July 2012 to July 2016 (Table 1). Mollusc species (23 gastropods,

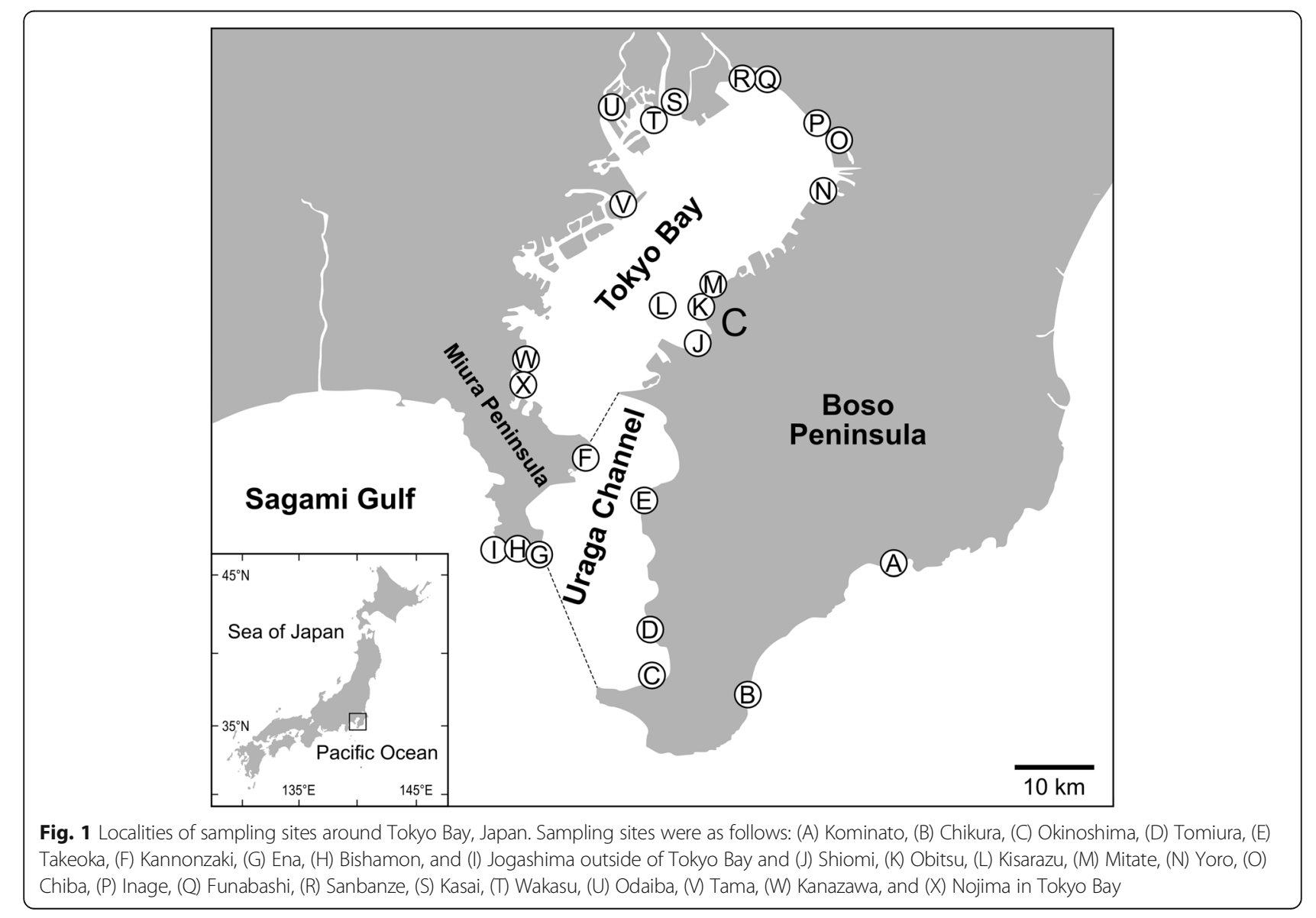




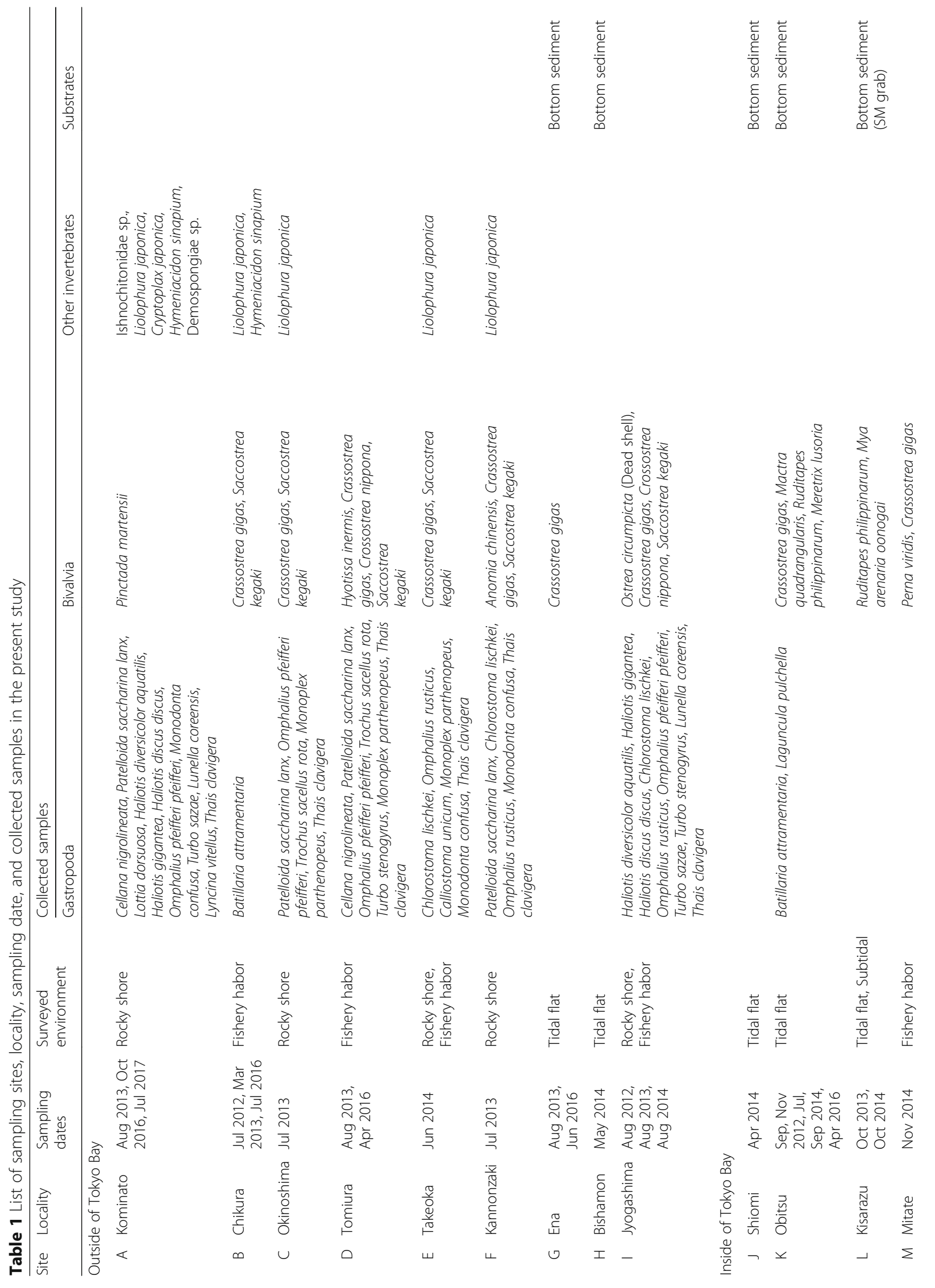




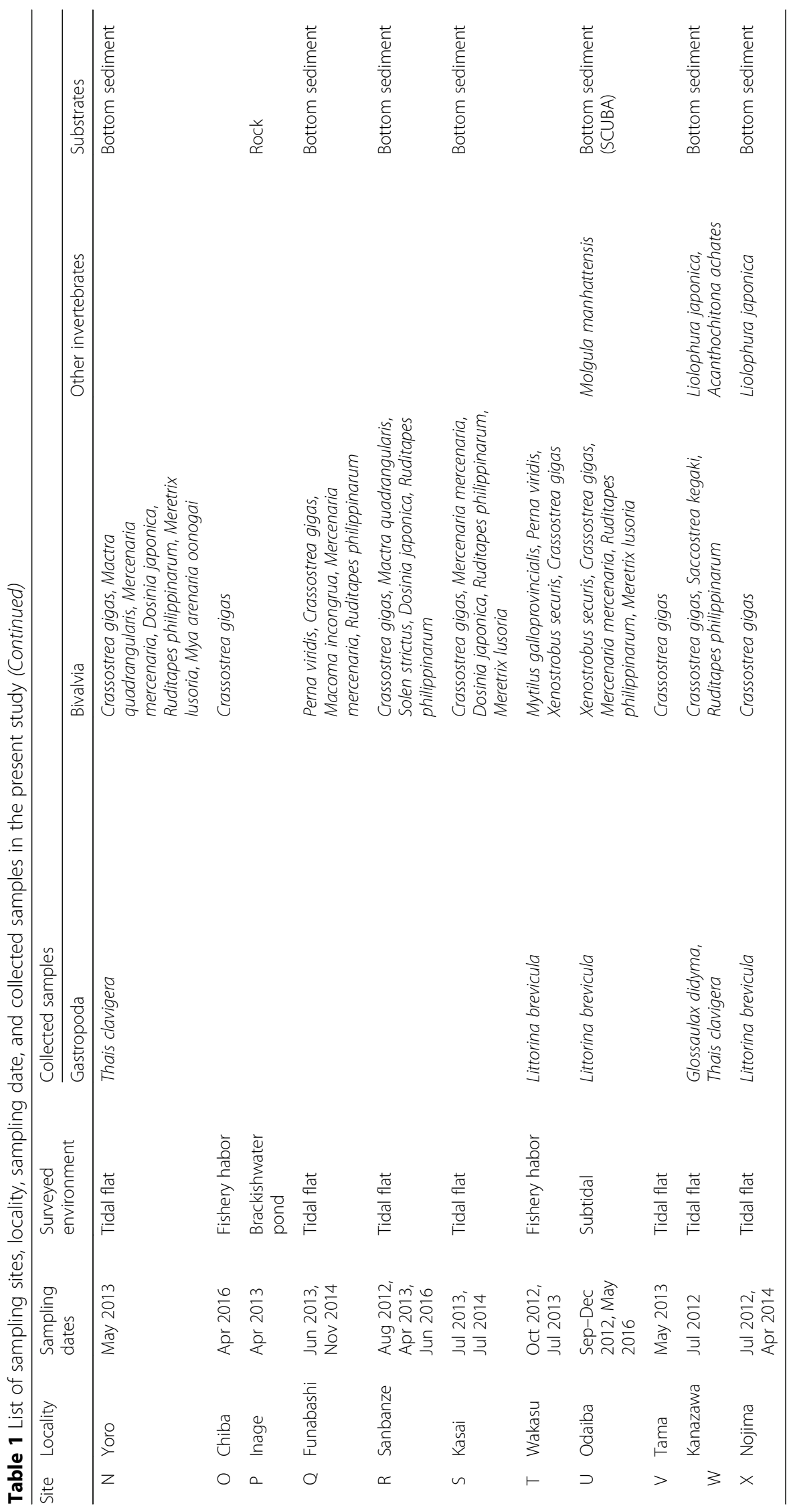


18 bivalves, and 4 chiton species) and other invertebrate species were obtained by sample collection from the intertidal or the upper part of the subtidal zone, and harvested molluscs with origin labels were also purchased at the sales office of the local fishery cooperatives (Table 1). Spionid individuals that excavated their burrows into shells of molluscs were extracted by fracturing the shells with cutting pliers. Individuals that inhabit interstitial habitats were collected from crevices between adherent substrates and the shell of oysters, which attached to rocks, concrete seawalls, and concrete slopes. Individuals that inhabit the bottom sediment were collected from the intertidal zone by sieving the sediment through $1-\mathrm{mm}$ mesh, and were collected from subtidal zones in Odaiba and off-Kisarazu (c.a. $20 \mathrm{~m}$ depth) by SCUBA and Smith-McIntyre grab sampler, respectively (Table 1). Collected spionids were identified under a stereomicroscope (MZ16A, Leica; SZX16, Olympus) and biological microscope (DM 4000B, Leica). They were classified as boring and non-boring (interstitial, epifaunal, and infaunal) species according to their habitat types (Fig. 2; Sato-Okoshi 1999, 2000).

To compare spionid fauna across study sites and spatial distribution trend across spionid species, cluster analysis with the group average linkage method and two-dimensional non-metric multidimensional scaling (nMDS: Anderson and Willis 2003) was conducted based on the Jaccard similarity coefficient matrix calculated from the presence/absence data matrices using R3.5.1 statistical software with the $\mathrm{R}$ package vegan (Oksanen et al. 2018). The hierarchical cluster dendrograms showing the similarity relationship of the sites and species were generated with colour mapping to graphically display presence/absence status of the species. To examine which environmental factors can explain the spatial pattern of the spionid fauna, correlations between the nMDS ordination by site and location (outside or inside of Tokyo Bay) and environment (rocky shore, fishery harbour, tidal flat, subtidal, and brackish water pond) of the study sites were calculated and plotted onto the ordination by using envfit function in the vegan (Oksanen et al. 2018). To examine whether the species spatial distribution trend can be explained by the species habitat types, correlations between the nMDS ordination by species and habitat type (boring, interstitial, epifaunal, and infaunal) were also calculated and plotted onto the ordination by using envfit function. Site $\mathrm{T}$ was excluded from these analyses due to inadequate data without any spionid species.

To examine host utilization pattern of the shell boring spionid polydorid species, cluster analysis was conducted based on the presence/absence data matrices of the mollusc species in the same manner as described above. The molluscs which were host to one or more

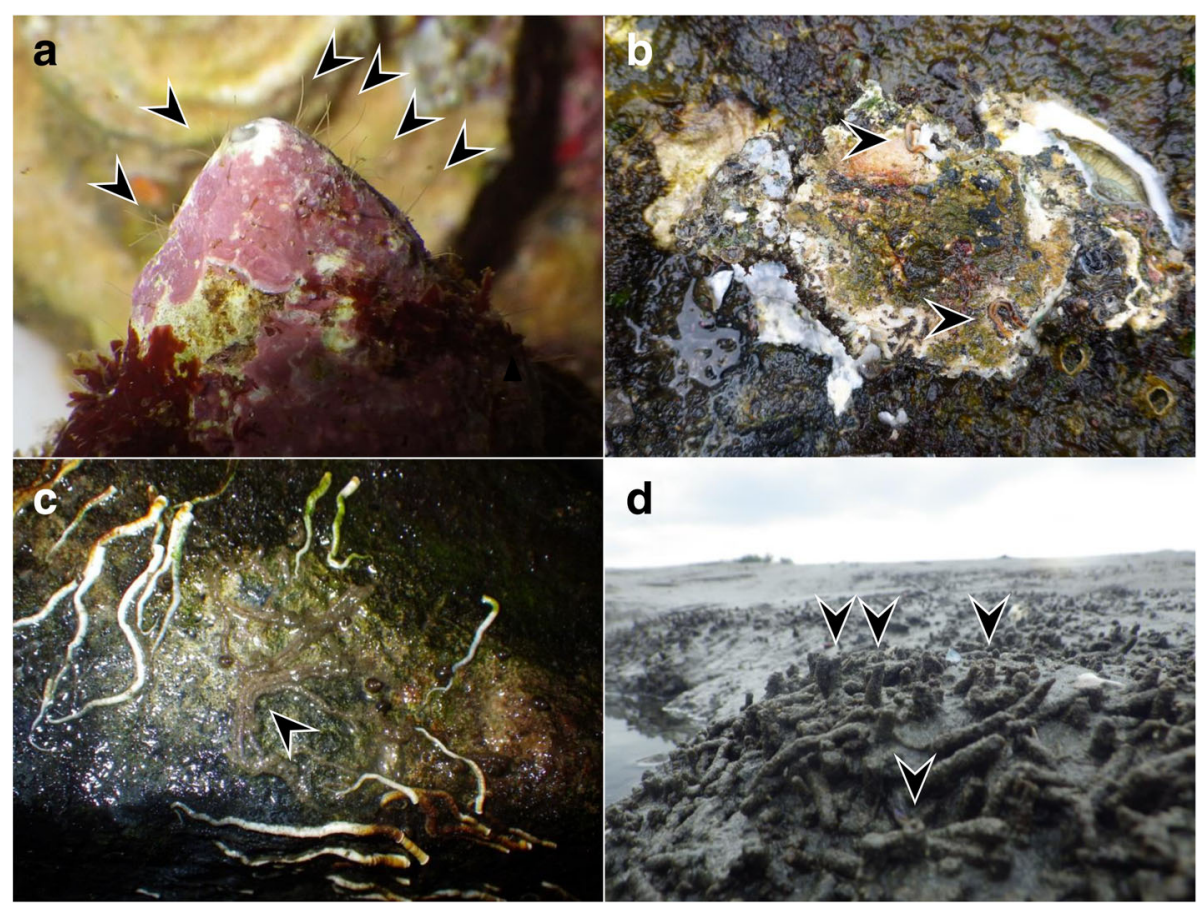

Fig. 2 Photographs showing various habitat types of spionid polychaetes. a Boring species, Polydora onagawaensis, inhabiting the shell of Omphalius pfeifferi pfeifferi (arrowed). b Interstitial species, Boccardia pseudonatrix, inhabiting mud in crevices of the oyster, Crassostrea gigas, shell and substrate (arrowed). c Epifaunal species, Carazziella spongilla, attaching to the rock surface (arrowed). d Infaunal species, Pseudopolydora cf. reticulata, constructing mud tubes in a tidal flat (arrowed) 
polydorids were graphically displayed as colour mapping with the hierarchical cluster dendrograms. Sites G, H, J, $\mathrm{L}$, and $\mathrm{P}$ were excluded from the analysis due to inadequate data without any mollusc species.

\section{Results}

\section{Spionid fauna around Tokyo Bay}

In total, 26 spionid species were collected from water areas around Tokyo Bay, of which eight, four, three, and 11 species were shell boring, interstitial, epifaunal, and infaunal spionid species, respectively (Fig. 3). The hierarchical cluster dendrograms calculated from the presence/ absence data showed a clear difference in the spionid fauna of hard (rocky shore and fishery harbour) and soft (tidal flat and subtidal) substrates (Fig. 3). Outside Tokyo Bay, a hard bottom environment is predominant, while inside Tokyo Bay a soft bottom environment is most common: This difference is reflected in the spionid fauna. Two-dimensional nMDS ordination showed significant correlation between the spatial pattern of the spionid fauna and location (outside and inside of Tokyo Bay) and environment (rocky shore and tidal flat) (Fig. 4a). Correlations between spatial distribution trend of each spionid species and their habitat types showed little significant relationship except for infaunal species (Fig. 4b).

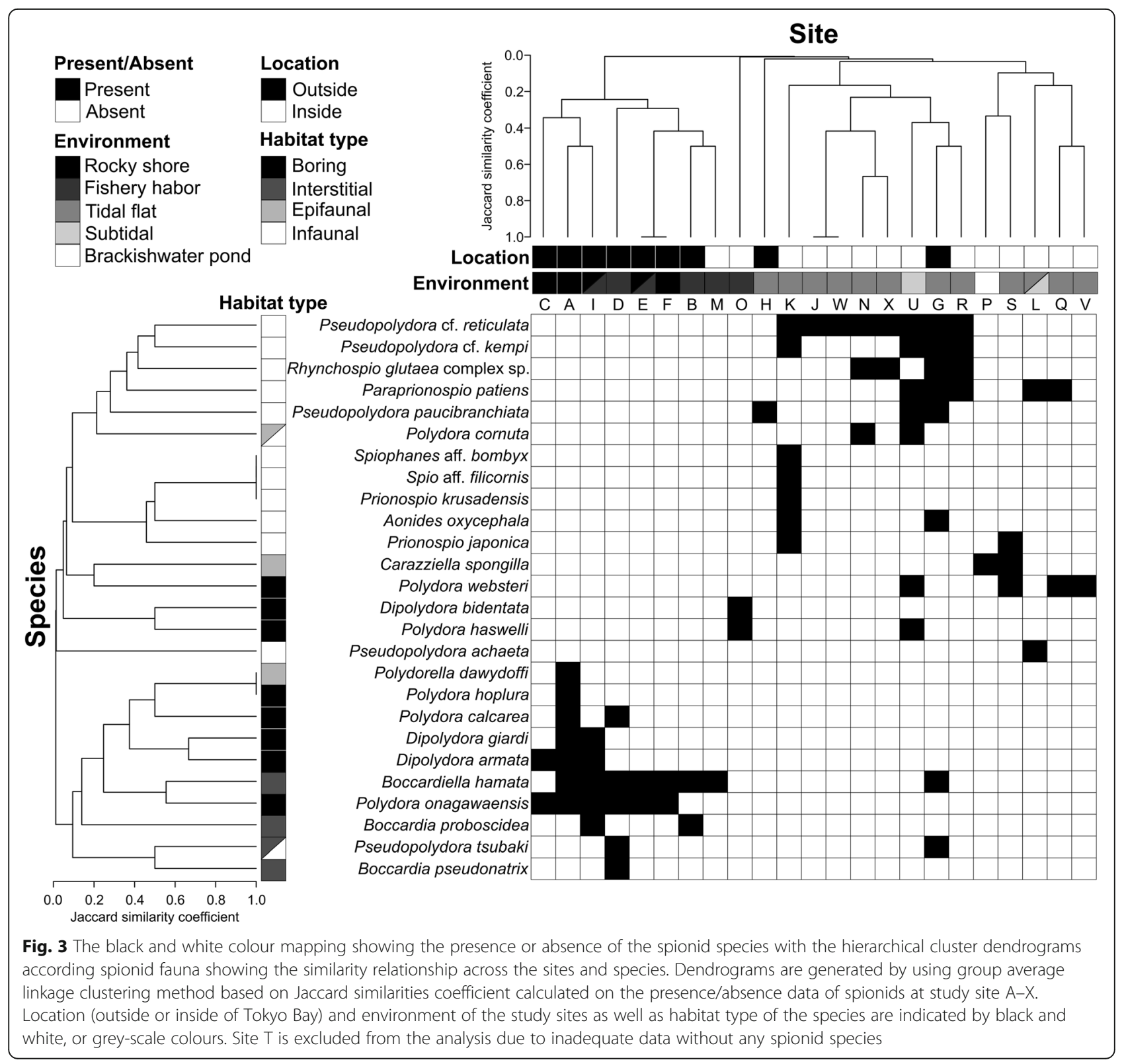



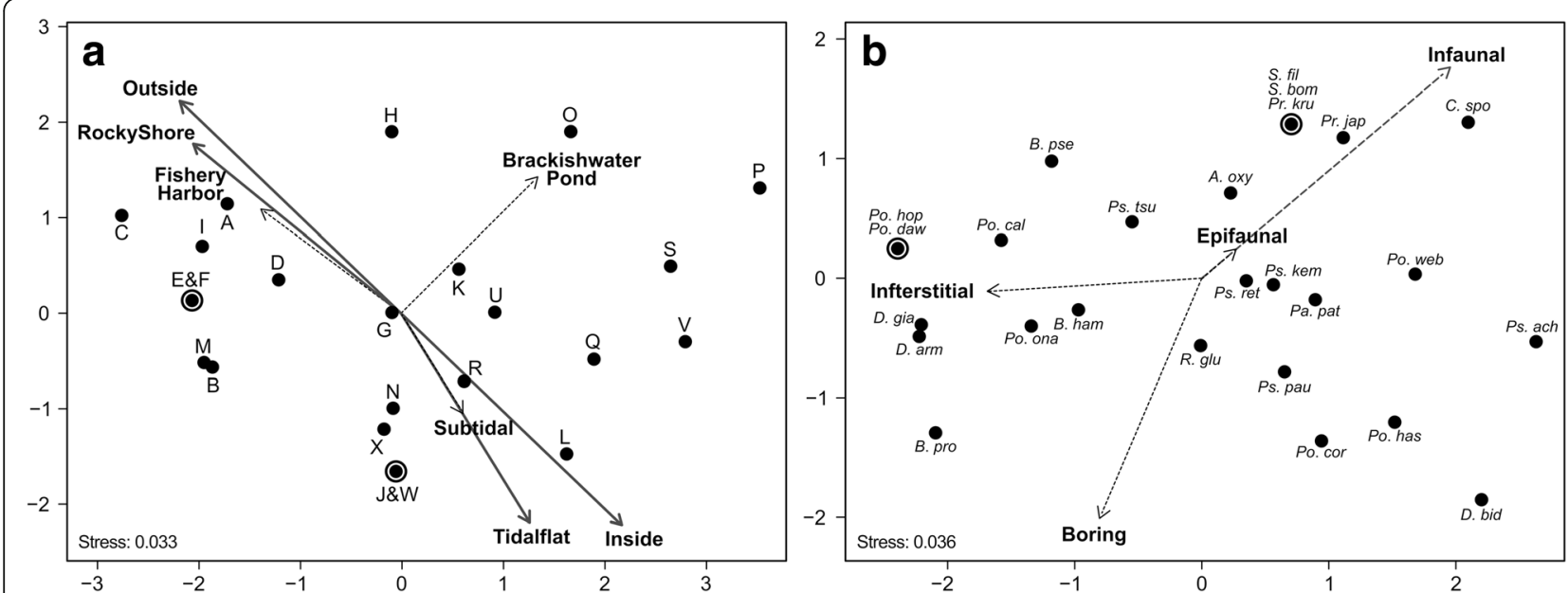

Fig. 4 Two-dimensional nMDS ordinations of sites (a) and species (b) based on Jaccard similarities coefficient calculated on the presence/ absence data of spionid fauna. Correlations between the ordination and environmental (a) or habitat type (b) vectors with $p$ value $<0.01,<0.05$, and $\geq 0.05$ are indicated by solid, dashed, and dotted lines of arrows, respectively, with the length of the arrows corresponding to the correlation strength. Complete overlap of the data points in nMDS ordinations are indicated by fisheye symbols. Site T is excluded from the analysis due to inadequate data without any spionid species. The data points of nMDS ordinations of species (b) are indicated by abbreviated species names: Po $\mathrm{cal}=$ Polydora calcarea, Po. ona = Polydora onagawaensis, Po. has = Polydora haswelli, Po. hop =Polydora hoplura, Po. web = Polydora websteri, D. arm = Dipolydora armata, D. gia = Dipolydora giardi, D. bid = Dipolydora bidentata, B. ham =Boccardiella hamata, B. pro = Boccardia proboscidea, B. pse $=$ Boccardia pseudonatrix, Ps. tsu $=$ Pseudopolydora tsubaki, C. spo = Carazziella spongilla, Po. daw = Polydorella dawydoffi, Po. cor $=$ Polydora cornuta, Ps. ach = Pseudopolydora achaeta, Ps. kem = Pseudopolydora cf. kempi, Ps. pau = Pseudopolydora paucibranchiata, Ps. ret = Peudopolydora cf. reticulata, S. fil =Spio aff. Filicornis, $R$. glu = Rhynchospio glutaea complex sp., S. bom = Spiophanes aff. bombyx, A. oxy = Aonides oxycephala, Pa. pat = Paraprionospio patiens, Pr. jap = Prionospio japonica, Pr. kru=Prionospio krusadensis

\section{Boring species}

In total, eight shell boring species of spionid polychaetes were collected from mollusc shells around Tokyo Bay (Fig. $3)$. The highest number of boring species was recorded at Kominato (site A) outside of Boso Peninsula (5 species) followed by Jogashima (site I) in the southernmost point of Miura Peninsula (3 species). In Tokyo Bay, the number of boring species tended to be low and only two boring species, Polydora haswelli and Polydora websteri, were collected. Polydora onagawaensis was the species collected from the largest number of sampling sites (6 sampling sites) at outside of Tokyo Bay.

Excavation of spionid polychaetes was confirmed in 8 gastropod and 3 bivalve species out of 22 gastropod and 10 bivalve species examined (Fig. 5). Spionid excavation of the shells of Polyplacophora, limpet and infaunal bivalves was not observed (excluded from analyses). The top shell Omphalius pfeifferi pfeifferi and the Pacific oyster Crassostrea gigas were the most frequently observed host shells that were bored by spionids. Spionid infestation of the top shell was observed in 3 spionid species at 4 sampling sites outside Tokyo Bay. Infestation of the oyster was observed in 4 spionid species at 1 sampling site outside Tokyo Bay and 5 sampling sites in Tokyo Bay (Fig. 5). The hierarchical cluster dendrograms calculated from the presence/absence data of mollusc species showed a difference of molluscan fauna between inside and outside Tokyo Bay except
Chikura (site B; Fig. 5). Overall, the diversity of molluscs was high outside Tokyo Bay and low inside it, while the number of mollusc species with spionid infestation tended to be higher outside of the bay and lower inside the bay.

\section{Interstitial and epifaunal species}

In total, four interstitial species of spionid polychaetes were collected from crevices between adherent substrates and the shells of oysters, which were attached to rocks, concrete seawalls, and concrete slopes (Fig. 3). Two of the interstitial species, Boccardiella hamata and Boccardia proboscidea, were also observed within the marine sponge Hymeniacidon sinapium in Kominato (site A) and Chikura (site B), respectively. Both species formed their tubes within tissues of the sponge (Fig. 6). Pseudopolydora tsubaki was collected from crevices between adherent substrates and the shells of oysters that had attached to concrete slopes in Tomiura (site D), while the species was also collected from muddy bottom sediment of the intertidal area in Ena Bay (site G). Interstitial species were frequently observed outside of Tokyo Bay, but were rarely observed in Tokyo Bay (Fig. 3). Boccardiella hamata showed a relatively wide distribution from Kominato (site A) to Kisarazu (site L). Conversely, the other three interstitial species were only collected from one or two sites. Boccardia pseudonatrix (Fig. 7) was 


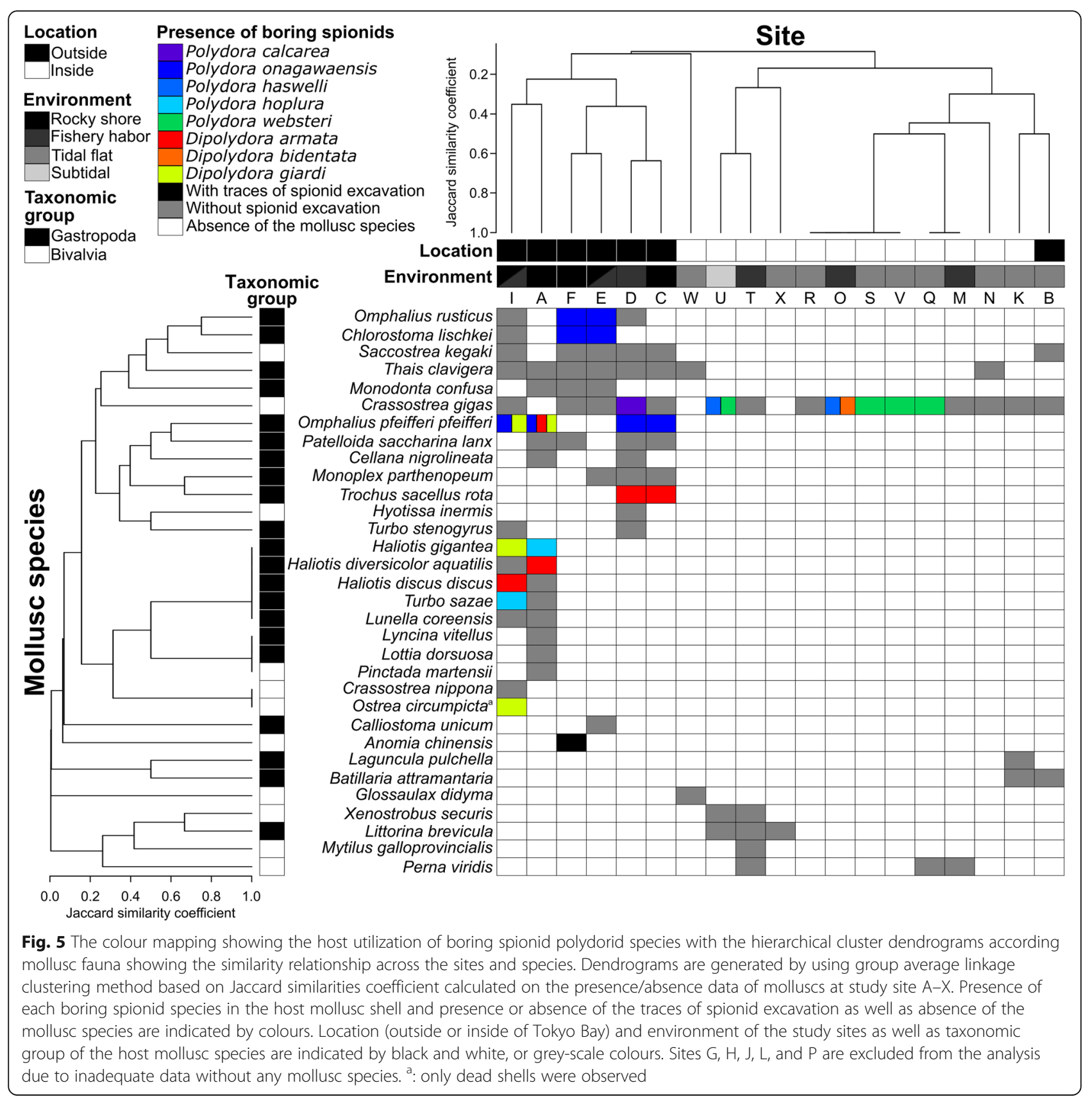

collected only from crevices between the shells of oysters and their adherent substrates in Tomiura (site D).

The three epifaunal species, Polydora cornuta, Carazziella spongilla, and Polydorella dawydoffi, which made mud or sand tubes on the substrate surface, were observed to attach onto a wide variety of substrates. Polydora cornuta was collected from the shell surface of Crassostrea gigas in Odaiba (site U) and Yoro (site N), the surface of exotic solitary ascidians Molgula manhattensis (Odaiba), and also from within mussel beds (Odaiba). Carazziella spongilla was collected from surface of rocks (Fig. 2C) in an artificial brackish water pond in Inage (site P) and the shell of oysters in brackish environments of Kasai (site S). Those epifaunal species were observed to inhabit only areas within Tokyo Bay (Fig. 3). Polydorella dawydoffi was only observed on the surface of a sponge species Demospongiae sp. at a rocky shore in Kominato (site A) outside of Tokyo Bay.

\section{Infaunal species}

In total, 11 infaunal spionid species were collected from bottom sediment around Tokyo Bay (Fig. 3). Infaunal species were often observed in Tokyo Bay but were rarely 


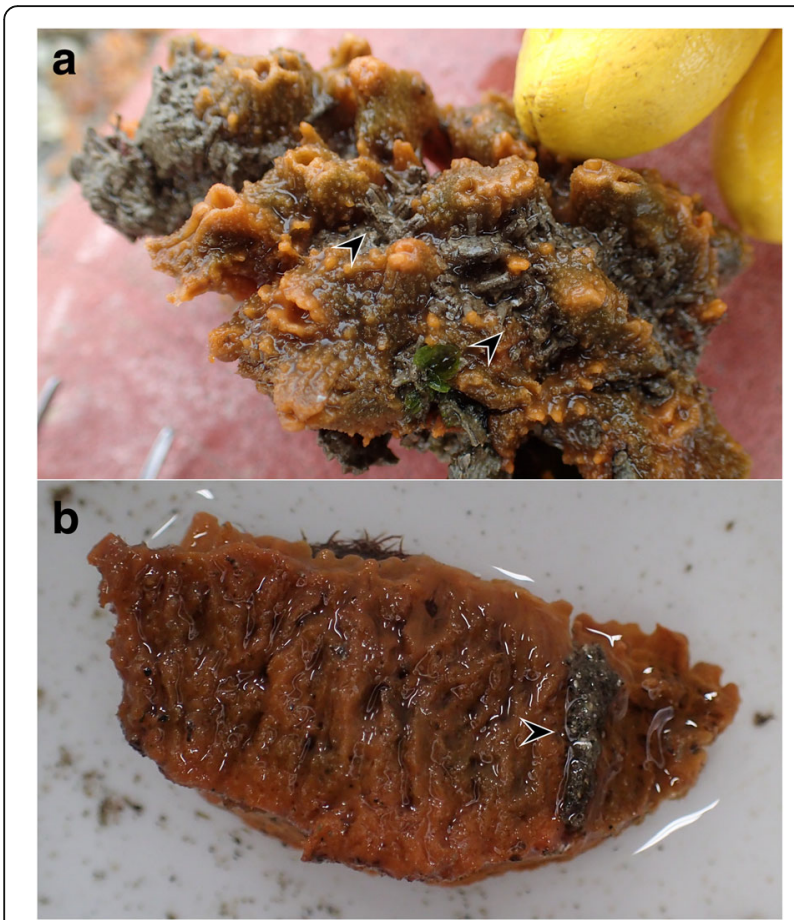

Fig. 6 Tubes of spionids protruding from the sponge Hymeniacidon sinapium. a The sponge collected from Kominato with a lot of tubes formed by Boccardiella hamata (overview). b The sponge collected from Chikura and torn to expose a tube formed by Boccardia proboscidea (cross section). Arrow heads indicate spionid tubes

collected from outside the bay, excluding Ena Bay (site G) in Miura Peninsula. Pseudopolydora cf. reticulata was the most frequently observed species (8 sites). Pseudopolydora cf. kempi and Ps. cf. reticulata, two morphologically similar species, occurred sympatrically in 4 sites: Ena (site G), Obitsu (site K), Sanbanze (site R), and Odaiba (site U). Pseudopolydora achaeta was collected only from sediment with a depth of $20 \mathrm{~m}$ off Kisarazu (site L). Pseudopolydora paucibranchiata was collected from muddy bottom sediment in 3 sites, below a depth of $5 \mathrm{~m}$ depth in Odaiba (site $\mathrm{U}$ ) and also from the periphery region of a seagrass (Zostera japonica) bed in the lower intertidal zone in Ena (site G) and Bishamon (site H).

\section{Discussion}

Novel species records and potential alien species in vicinity of Tokyo Bay

In the present study, 11 spionid species, Polydora calcarea, Polydora onagawaensis, Dipolydora bidentata, Dipolydora giardi, Boccardiella hamata, Boccardia proboscidea, Boccardia pseudonatrix, Pseudopolydora tsubaki, Carazziella spongilla, Polydorella dawydoffi, and Pseudopolydora achaeta were recorded for the first time from the vicinity of Tokyo Bay, including the Boso and Miura Peninsulas. As almost all of them have been already recorded within Japan (Sato-Okoshi 1999, 2000;
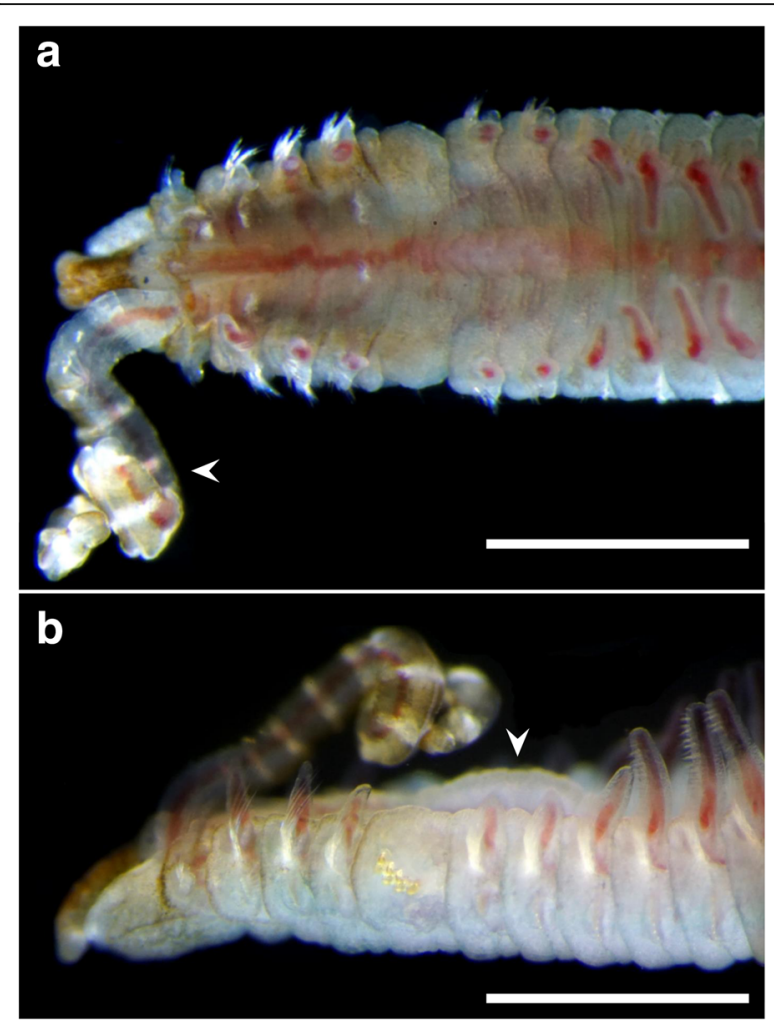

Fig. 7 Boccardia pseudonatrix collected from mud in crevices of oyster shells and adherent substrates (concrete slopes) in Tomiura, Boso Peninsula. a Anterior, dorsal view of living individual. White bands are present on the palp (arrowed). Palp on right side is lacking. b Anterior, lateral view of living individual. A mid-dorsal ridge is present from chaetiger 5 to the middle of chaetiger 8 (arrowed). Scale bars: A, B $=1 \mathrm{~mm}$

Sato-Okoshi and Abe 2013; Teramoto et al. 2013; Abe et al. 2014, 2016; Yamada and Hoshino 2014; Simon et al. 2019), these species were considered to be native to Japan or questionable in origin. It is noteworthy that Boccardia pseudonatrix (Fig. 7) was recorded for the first time from Japan with clear locality information (see Sato-Okoshi et al. 2015, as extracted from oyster Crassostrea gigas). This species is considered to be a potential alien species because the species has, until now, only been recorded from localities distant from Japan: South Africa (Day 1967; Simon et al. 2010) and Australia (Blake and Kudenov 1978; Sato-Okoshi et al. 2008, as B. knoxi: see Sato-Okoshi et al. 2015; Walker 2013), despite they have relatively low natural dispersal ability due to adelphophagic development without long planktonic larval phase (Simon 2015).

\section{Habitat utilization by spionid polychaetes}

In the present study, the shell boring spionids usually inhabited multiple species of mollusc shells (Fig. 5), as reported in previous studies (Sato-Okoshi 1999, Simon and Sato-Okoshi 2015), while a certain degree of limitation in 
host utilization was assumed. Only one third of the mollusc species examined were bored by spionids even though molluscan species had overlapping distributions (Fig. 5). The factors responsible for restricting the molluscan species bored are unclear, but it should be noted that boring by spionids has seldom been reported from supralittoral and/or upper-intertidal gastropods (e.g. Littorina brevicula), deep burrowing infaunal bivalves (e.g. Ruditapes philippinarum), and species with iron rich (chitons and some limpets; Okoshi, unpublished data) or very thin shells (e.g. Mytilus galloprovincialis). It is also interesting to note that spionid borings have not been observed on the shells of Monodonta confusa and Thais clavigera in the present study and previous studies (e.g. Sato-Okoshi 1999), in spite of their habitat depth (lower intertidal and subtidal zones) where the spionids occurred in other sympatric gastropods such as Chlorostoma lischkei and Omphalius rusticus (Fig. 5).

Non-boring spionids were collected from a wide variety of substrates and were grouped into three habitat types: interstitial, epifaunal, and infaunal species (Fig. 2). Nonpolydorid spionids (i.e. species other than polydorids) were found only in infaunal habitats. In contrast, polydorid species showed diverse habitats (Fig. 3). Four polydorid species, Boccardiella hamata, Boccardia proboscidea, Boccardia pseudonatrix, and Pseudopolydora tsubaki utilized interstitial habitats such as mud deposition in crevices between oyster shells and their adherent substrates. Boccardiella hamata and Boccardia proboscidea were also collected from within a sponge, which represents a novel habitat for the two species (Fig. 6). The infaunal species, Pseudopolydora cf. kempi and Pseudopolydora cf. reticulata, mainly occurred in intertidal mud/ sand flats. In contrast, other infaunal Pseudopolydora paucibranchiata and Pseudopolydora achaeta were usually collected from and considered to prefer a muddy subtidal environment. Pseudopolydora paucibranchiata were occasionally collected from lower intertidal areas, but Pseudopolydora achaeta was collected only from muddy sediment in $20 \mathrm{~m}$ depth off Kisarazu (site L, Fig. 3). Because the previous study also reported deep distribution (at a $20 \mathrm{~m}$ depth) of Pseudopolydora achaeta (Abe et al. 2016), it appears that the species prefers the deepest environment of the six known Japanese Pseudopolydora species.

In the epifaunal spionids, Carazziella spongilla was considered to be a brackish species because it was collected only from low salinity environments. Carazziella spongilla was originally described as inhabiting brackish Lake Shinji, Japan, where the salinity ranged from 0.7 to 2.0\%o (Sato-Okoshi 1998). In the present study, C. spongilla made a mud tube and attached it to rocks or oysters (Fig. 2c), so habitat selectivity of the species was different from the original description, which reported that this species forms mud tubes in the freshwater sponge Spongilla alba (Sato-Okoshi 1998). Thus, we concluded that this species is not host specific but utilizes a variety of substrates as epifaunal habitat in brackish environments. Another epifaunal species, Polydora cornuta, was collected for the first time from the surface of the exotic solitary ascidians Molgula manhattensis, which represents a novel habitat of the species.

\section{Distribution of spionid polychaetes around Tokyo Bay}

The distribution of boring spionids is assumed to be greatly influenced by both the distribution of their potential host molluscs and their own environmental preferences. In the present study, almost all boring spionids except for Polydora haswelli, Polydora websteri, and Dipolydora bidentata were collected only from relatively open environments outside of Tokyo Bay. These spionids excavated into the host shells, which were mainly distributed in the open environment and rarely distributed in Tokyo Bay. In the eutrophic Tokyo Bay, the anoxic blue tide that often occurs in summer and/or autumn seriously damages marine organisms, especially subtidal benthic species (Takeda et al. 1991). Such damage precludes the existence of the molluscan hosts especially in the most inner part of the bay. This in turn limits the distribution of boring spionids, especially subtidal species, Dipolydora giardi and Polydora hoplura (previously recorded as Polydora uncinata in Japan: see Sato-Okoshi et al. 2017; Radashevsky and Migotto 2017), which were collected mostly from subtidal gastropods in the present and previous studies (Sato-Okoshi 1999; Sato-Okoshi and Abe 2012). Large molluscs such as the scallop Patinopecten yessoensis, subtidal limpet Niveotectura pallida (as Acmaea pallida), and abalone, which spionids had often infested in the previous study (Sato-Okoshi 1999), do not distribute in or rarely inhabit Tokyo Bay. Absence of available host shells in the bay may be one reason why there are few boring spionid species in Tokyo Bay. Even Polydora onagawaensis, which is known to bore into Crassostrea gigas (Teramoto et al. 2013), was not collected from the inner part of Tokyo Bay in the present study. Therefore, this species is assumed to prefer the open sea environment.

Polydora haswelli and Polydora websteri were collected only from the shells of Crassostrea gigas in the inner part of Tokyo Bay (Fig. 3). Polydora websteri is a well-known, presumably cosmopolitan species, known to bore into the shells of various mollusc species worldwide (Blake 1996; Sato-Okoshi 1999; Read 2010). This species inhabits hosts associated with muddy environments, particularly oyster beds (Sato-Okoshi and Abe 2013). It is considered to prefer enclosed embayment and not to have a specific preference for the host shell oysters. It is 
also suggested that Polydora haswelli, the sister species of Polydora websteri (Sato-Okoshi and Abe 2013), have similar habitat preferences.

The distribution trends of four interstitial spionids (Boccardiella hamata, Boccardia proboscidea, Boccardia pseudonatrix, and Pseudopolydora tsubaki) were somewhat variable: Boccardiella hamata was distributed widely outside of Tokyo Bay: Kominato (site A), Chikura (site B), Tomiura (site D), Takeoka (site E), Kannonzaki (site F), Ena (site G), and Jogashima (I) and only one site in Tokyo Bay: Mitate (site M), while Boccardia proboscidea, Boccardia pseudonatrix, and Pseudopolydora tsubaki were collected from a small number of sites outside Tokyo Bay: Chikura (site B), Tomiura (site D), Ena (site G), and Jogashima (site I) (Fig. 3). These results indicate that the interstitial species prefers relatively open environments; a highly enclosed environment may not be suitable as they have never been collected from the innermost part of Tokyo Bay despite an abundance their preferred host, Pacific oysters. Furthermore, the distribution of interstitial species is may well be influenced by their mode of reproduction. The widely distributed Boccardiella hamata has long-term planktonic larval development (Dean and Blake 1966), while the more patchy Boccardia proboscidea and Boccardia pseudonatrix have adelphophagic development with short or no planktonic larval stages (Sato-Okoshi 2000; Simon 2015). Although Boccardia proboscidea is well known as a poecilogonous species (Gibson 1997), only direct development has been reported in this species in Japan (Sato-Okoshi 2000).

Different distribution trends among congeneric infaunal species was found in the genus Pseudopolydora. In Tokyo Bay, Pseudopolydora cf. kempi had been known as one of the most dominant species inhabiting soft-bottom habitats in estuaries and tidal flats (e.g., Nishi et al. 2007, 2009, 2010). However, it was recently reported that the morphologically similar species, Pseudopolydora cf. reticulata, had been confused as Pseudopolydora cf. kempi in Japan (Abe et al. 2016). In the present study, it was revealed that Pseudopolydora cf. reticulata was widely distributed in Tokyo Bay, while Pseudopolydora cf. kempi was distributed in a relatively limited area in Tokyo Bay (Fig. 3). This observation indicates the possibility that Pseudopolydora cf. reticulata is more common and abundant in Tokyo Bay than Pseudopolydora cf. kempi. The distribution pattern of these two infaunal species may be related to their reproductive features: that is, the widely distributed Pseudopolydora cf. reticulata has long-term planktonic larval development while the more locally distributed Pseudopolydora cf. kempi shows shortterm planktonic larval or direct development (Kondoh et al. 2017).

\section{Acknowledgments}

We would like to express our sincere appreciation to Wataru Teramoto (Fukushima Prefectural Inland Water Fisheries Experimental Station) and Tomohiko Kondoh (Tohoku University) for valuable comments during the course of this study; Masaatsu Tanaka (Kagoshima University), Tomohito Ojima, Masako Ojima (Research Group of Aquatic Life in Port of Tokyo) for providing specimens; Masahiro Suzuki, Yuka Ohashi, the other members of Laboratory of Marine Ecology, Faculty of Science, Toho University, and Captain Hayashi and the crew of the Shinyo Maru, Tokyo University of Marine Science and Technology for valuable assistance in field sampling; Robin Wilson (Museum Victoria) and the two anonymous reviewers for their very helpful and constructive comments on earlier versions of this manuscript.

\section{Funding}

Not applicable.

\section{Availability of data and materials}

All data generated or analysed during this study are included in this published article.

\section{Authors' contributions}

Research design: TT, KO. Sample collection: HA, TT, MT, KO. Specimen examination: HA, TT, MT, WS-O. Data analyses: HA. Drafted the manuscript: HA. Supervision: WS-O, KO. All authors have read and approved the final manuscript.

Ethics approval and consent to participate

Not applicable.

\section{Consent for publication}

Not applicable.

\section{Competing interests}

The authors declare that they have no competing interests.

\section{Publisher's Note}

Springer Nature remains neutral with regard to jurisdictional claims in published maps and institutional affiliations.

\section{Author details}

${ }^{1}$ Department of Biology, Center for Liberal Arts \& Sciences, Iwate Medical University, 2-1-1 Nishitokuta, Yahaba-cho, Shiwa-gun, Iwate 028-3694, Japan. ${ }^{2}$ Department of Environmental Science, Faculty of Science, Toho University, 2-2-1 Miyama, Funabashi, Chiba 274-8510, Japan. ${ }^{3}$ Tokyo Bay Ecosystem Research Center, Toho University, 2-2-1 Miyama, Funabashi, Chiba 274-8510, Japan. ${ }^{4}$ Funabashi Sanbanze Seaside Park, Funabashi City Park Foundation, 40 Shiomicho, Funabashi, Chiba 273-0016, Japan. ${ }^{5}$ Laboratory of Biological Oceanography, Graduate School of Agricultural Science, Tohoku University, Sendai 980-8572, Japan.

Received: 6 May 2018 Accepted: 10 April 2019

Published online: 02 May 2019

\section{References}

Abe H, Kondoh T, Sato-Okoshi W. First report of the morphology and rDNA sequences of two Pseudopolydora species (Annelida: Spionidae) from Japan Zool Sci. 2016;33:650-8.

Abe H, Sato-Okoshi W, Nishitani G, Endo Y. Vertical distribution and migration of planktonic polychaete larvae in Onagawa Bay, northeastern Japan. Mem Mus Vic. 2014;71:1-9.

Anderson MJ, Willis TJ. Canonical analysis of principal coordinates: a useful method of constrained ordination for ecology. Ecology. 2003;84:511e525.

Asakura A. Recent introductions of marine benthos into Tokyo Bay (review): process of invasion into an urban ecosystem with discussion on the factors inducing their successful introduction. J Nat Hist Mus Inst Chiba. 1992;2:1-14 (in Japanese with English abstract).

Blake JA. Family Spionidae Grube, 1850. In: Blake JA, Hilbig B, Scott PH, editors. Taxonomic Atlas of the Benthic Fauna of the Santa Maria Basin and the Western Santa Barbara Channel, vol. 6. Santa Barbara (CA): Santa Barbara Museum of Natural History; 1996. p. 81-223. 
Blake JA, Arnofsky P. Reproduction and larval development of the spioniform Polychaeta with application to the systematics and phylogeny. Hydrobiologia. 1999;402:57-106.

Blake JA, Evans JW. Polydora and related genera as borers in mollusk shells and other calcareous substrates. Veliger. 1972;15:235-49.

Blake JA, Kudenov JD. The Spionidae (Polychaeta) from southeastern Australia and adjacent areas, with a revision of the genera. Mem Nat Mus Vic. 1978;39: $171-280$.

Carlton JT. Transoceanic and interoceanic dispersal of coastal marine organisms: the biology of ballast water. Oceanogr Mar Biol Annu Rev. 1985;23:313-71.

Çinar ME. Alien polychaete species worldwide: current status and their impacts. J Mar Biol Assoc UK. 2013;93:1257-78.

Dauer DM, Maybury CA, Ewing RM. Feeding behavior and general ecology of several spionid polychaetes from the Chesapeake Bay. J Exp Mar Biol Ecol. 1981;54:21-38.

Day JH. A monograph on the Polychaeta of southern Africa. Part 2 Sedentaria. London: Trustees of the British Museum (Natural History); 1967.

Dean D, Blake JA. Life-history of Boccardia hamata (Webster) on the east and west coasts of North America. Biol Bull. 1966;130:316-30.

Furukawa K, Okada T. Tokyo Bay: its environmental status — past, present, and future. In: Wolanski E, editor. The environment in Asia Pacific Harbours. Netherlands: Springer; 2006. p. 15-34.

Gibson GD. Variable development in the spionid Boccardia proboscided (Polychaeta) is linked to nurse egg production and larval trophic mode. Invertebr Biol. 1997;116:213-26.

Glasby CJ, Timm T. Global diversity of polychaetes (Polychaeta; Annelida) in freshwater. Hydrobiologia. 2008;595:107-15.

Iwasaki K. Human-mediated introduction of marine organisms in Japan: a review. In: Koike F, Clout MN, Kawamichi M, De Poorter M, Iwatsuki K, editors. Assessment and control of biological invasion risks. Kyoto, Japan: Shoukadoh Book Sellers, and Switzerland: IUCN, Gland; 2006. p. 104-12.

Katsanevakis S, Wallentinus I, Zenetos A, Leppäkoski E, Çinar ME, Oztürk B, Grabowski M, Golani D, Cardoso AC. Impacts of invasive alien marine species on ecosystem services and biodiversity: a pan-European review. Aquat Invasions. 2014;9:391-423.

Kondoh T, Abe H, Sato-Okoshi W. Reproduction and larval development of two sympatric Pseudopolydora species (Annelida: Spionidae) in Japan. Invertebr Reprod Dev. 2017:61:172-81.

Nishi E, Kudo T, Nakayama S, Masumoto T, Tanaka K, Itou T, Suwabe H, Sakamoto A, Kimura T, Mizuo H, Hayakawa K. Benthos fauna after the algal red tide of spring, 2003 at Nojima coast, Yokohama, Central Japan. Nat Hist Rep Kanagawa. 2007;28:109-14. (in Japanese).

Nishi E, Masumoto T, Taru M, Nakayama S, Kazama-Wakabayashi M, Monju M, Suyama N, Aida M, Sato M, Tanaka K, Kupriyanova EK. Polychaete fauna and diversity around Haneda, Tokyo Bay, a result of environmental assessment of Haneda airport re-expansion project. In: Proceedings of the $21^{\text {st }}$ ocean engineering symposium. Tokyo: JFOES \& JASNAOE; 2009. p. 1-8. (in Japanese with English abstract)

Nishi E, Ueda I, Sakamoto A, Murakami-Sugihara N, Shimosako K, Sanada S. Benthos fauna of artificially created tidal flats in Yokohama port, Tokyo Bay Nat Hist Rep Kanagawa. 2010;31:29-33 (in Japanese).

Oksanen J, Blanchet FG, Friendly M, Kindt R, Legendre P, McGlinn D, Minchin PR, O'Hara RB, Simpson GL, Solymos P, Stevens MHH, Szoecs E, Wagner H. Vegan: community ecology package. R package version 2.5-2. 2018. https:// CRAN.R-project.org/package=vegan. Accessed 18 Aug 2018.

Paterson GL, Neal L, Altamira I, Soto EH, Smith CR, Menot L, Billett DSM, Cunha MR, Marchais-Laguionie C, Glover AG. New Prionospio and Aurospio species from the Deep Sea (Annelida: Polychaeta). Zootaxa. 2016;4092:1-32.

Radashevsky VI, Migotto AE. First report of the polychaete Polydora hoplura (Annelida: Spionidae) from North and South America and Asian Pacific. Mar Biodivers. 2017:47:859-68

Radashevsky VI, Olivares C. Polydora uncinata (Polychaeta: Spionidae) in Chile: an accidental transportation across the Pacific. Biol Invasions. 2005;7:489-96.

Radashevsky VI, Pankova W. Shell-boring versus tube-dwelling: is the mode of life fixed or flexible? Two cases in spionid polychaetes (Annelida, Spionidae). Mar Biol. 2013;160:1619-24.

Read GB. Comparison and history of Polydora websteri and P. haswelli (Polychaeta: Spionidae) as mud-blister worms in New Zealand shellfish. New Zeal J Mar Fresh Res. 2010;44:1-18.

Sato-Okoshi W. Three new species of polydorids (Polychaeta, Spionidae) from Japan. Spec Div. 1998;3:277-88.
Sato-Okoshi W. Polydorid species (Polychaeta: Spionidae) in Japan, with descriptions of morphology, ecology and burrow structure. 1. Boring species. J Mar Biol Assoc UK. 1999;79:831-48.

Sato-Okoshi W. Polydorid species (Polychaeta: Spionidae) in Japan, with descriptions of morphology, ecology and burrow structure. 2. Non-boring species. J Mar Biol Assoc UK. 2000;80:443-56.

Sato-Okoshi W, Abe H. Morphology and molecular sequence analysis of the harmful shell boring species of Polydora (Polychaeta: Spionidae) from Japan and Australia. Aquaculture. 2012;368-369:40-7.

Sato-Okoshi W, Abe H. Morphology and molecular analysis of the $18 \mathrm{~S} r$ RNA gene of oyster shell borers, Polydora species (Polychaeta: Spionidae), from Japan and Australia. J Mar Biol Assoc UK. 2013;93:1279-86.

Sato-Okoshi W, Abe H, Okoshi K, Teramoto W, Shaw S, Koh B-S, Kim Y-H, Hong JS, Li J-Y. Harmful shell borers, Polydora species (Polychaeta: Spionidae), from commercially important mollusk shells in East Asia and Australia. In: Ceccaldi $\mathrm{H}-\mathrm{J}$, et al., editors. Marine productivity: perturbations and resilience of socioecosystems. Switzerland: Springer International Publishing; 2015. p. 31-42.

Sato-Okoshi W, Abe H, Nishitani G, Simon CA. And then there was one: Polydora uncinata and Polydora hoplura (Annelida: Spionidae), the problematic polydorid pest species represent a single species. J Mar Biol Assoc UK. 2017; 97:1675-84.

Sato-Okoshi W, Okoshi K, Koh B-S, Kim Y-H, Hong J-S. Polydorid species (Polychaeta: Spionidae) associated with commercially important mollusk shells in Korean waters. Aquaculture. 2012;350-353:82-90.

Sato-Okoshi W, Okoshi K, Shaw J. Polydorid species (Polychaeta: Spionidae) in south-western Australian waters with special reference to Polydora uncinata and Boccardia knoxi. J Mar Biol Assoc UK. 2008;88:491-501.

Simon CA. Observations on the composition and larval developmental modes of polydorid pests of farmed oysters (Crassostrea gigas) and abalone (Haliotis midae) in South Africa. Invertebr Reprod Dev. 2015;59:124-30.

Simon CA, Sato-Okoshi W. Polydorid polychaetes on farmed molluscs: distribution, spread and factors contributing to their success. Aquacult Environ Interact. 2015;7:147-66.

Simon CA, Sato-Okoshi W, Abe H. Hidden diversity within the cosmopolitan species Pseudopolydora antennata (Claparède, 1869) (Spionidae: Annelida). Mar Biodivers. 2019;49:25-42.

Simon CA, Worsfold TM, Lange L, Sterley J. The genus Boccardia (Polychaeta: Spionidae) associated with mollusc shells on the south coast of South Africa. J Mar Biol Assoc UK. 2010;90:585-98.

Sukigara C, Saino T. Temporal variations of $\delta^{13} \mathrm{C}$ and $\delta^{15} \mathrm{~N}$ in organic particles collected by a sediment trap at a time-series station off the Tokyo Bay. Continent Shelf Res. 2005;25:1749-67.

Takeda S, Nimura Y, Hirano R. Optical, biological, and chemical properties of Aoshio, hypoxic milky blue-green water, observed at the head of Tokyo Bay. J Oceanogr Soc Jpn. 1991;47:126-37.

Teramoto W, Sato-Okoshi W, Abe H, Nishitani G, Endo Y. Morphology, 18S rRNA gene sequence and life history of a new Polydora species (Polychaeta: Spionidae) from northeastern Japan. Aquat Biol. 2013;18:31-45.

Walker LM. A revision of the Polydora-complex (Annelida: Spionidae) fauna from Australia. PhD thesis. Australia: University of Queensland; 2013. p. 300

Yamada K, Hoshino O. Esperiopsis plumosa Tanita 1965 (Esperiopsidae, Demospongiae) declined by a commensal polychaete Polydorella dawydoffi Radashevsky 1996 (Spionidae), Izu Oshima Island, Japan. Bull Biogeograph Soc Jpn. 2014;69:189-91 (in Japanese).

Ready to submit your research? Choose BMC and benefit from:

- fast, convenient online submission

- thorough peer review by experienced researchers in your field

- rapid publication on acceptance

- support for research data, including large and complex data types

- gold Open Access which fosters wider collaboration and increased citations

- maximum visibility for your research: over $100 \mathrm{M}$ website views per year

At $\mathrm{BMC}$, research is always in progress.

Learn more biomedcentral.com/submissions 